\title{
A BIBLI : IRAPHICAL GUIDE TO SECONDARY SOURCES ON THE HISTORY OF THE SOUTH AFRICAN NATIONAL DEFENCE FORCE, 1912-1995
}

\author{
Compiled by Major I.J. van der Waag \\ Documentation Service Directorate, National Defence Force
}

Ideally, an historian, if he is to acquit his task, must know the total range and types of sources available to him, in and around the topic of his enquiry. Knowing what his colleagues have published is essential. However, it is hardly possible to compile, and keep up to date, a full bibliography. Selection is both subjective and arbitrary; and a selection of books, articles and manuscripts is no exception.

Nonetheless, a serious researcher will attempt to make a survey of all the material, archival and secondary, which may conceivably be relevant to his topic. Geoffrey Elton has described this as "a broadfronted attack upon all the relevant material". ${ }^{\text {T }}$ This is of primary importance to historical scholarship. First and foremost, it is pointless to duplicate work once all the major issues and questions involved, have already been thrashed out by other historians. It has been said that history is an endless debate. This is true. However, debating historians must have something to say. An historian tackling a hackneyed topic, must either have discovered new evidence or must advance a novel interpretation of existing evidence.

Secondly, by consulting the works of a variety of colleagues, the historian can pick up the historical dialogue on his topic and gain access to a very large body of knowledge "accepted" by the broad historical community. In so doing, he can identify potentially important questions and lines of fruitful discussion.

Thirdly, such a "broad-fronted attack" is the only reasonable way to cover the range of archival sources as it is impossible for one historian to see all the evidence relating to his topic. By consulting secondary works, he gains access to knowledge based on archival sources which he may not be able to consult for himself.

Clearly then, the historian must acquaint himself with the body of published knowledge. For the sake of convenience, this bibliographical guide, which represents the first reasonably comprehensive attempt to show what has been written on the military history of South Africa since 1912, has been divided into the following categories:
1. Historiography, Method and Sources
2. General
3. Formative Years
4. First World War
5. The Interwar Years 1919-1939
6. Second World War
7. African Defence, the Commonwealth and the Cold War
8. Consolidation, Protest and Liberation
9. Southern Africa campaign 1968-1989
10. Corps, Regimental and Unit Histories
11. Administrative and Office Histories
12. Regional
13. Social
14. Military Culture
15. Messes, Canteens and Entertainment
16. Uniforms and Medals
17. Conservation
18. Biography and Autobiography

Most of these works are available at the Documentation Service Directorate, either in the reading rooms of the Military Archives Depot or through one 
of the twenty-three National Defence Force reference libraries.

\section{HISTORIOGRAPHY, METHOD AND SOURCES}

Anon. ' $\mathrm{n}$ Kort geskiedenis van die Militêre Informasieburo, Archives news Jul 1983 : 38-46.

Barnard, S.L. Die Suid-Afrikaanse "Grensoorlog", 1966 tot 1989: Militêre historici by die kruispad. Bloemfontein, 6 Oct 1993.

Combrinck, J.A. Aardrykskunde (Geografie) as aangrensende wetenskap tot die geskiedenis, Militaria 10(3) 1980 : 40-47.

Combrinck, J.A. Die Geskiedenis, lief en leed van die SAW Argief, Archives news Jul 1988 : 3748.

Combrinck, J.A. Die Ontstaan en Ontwikkeling van die SAW-Argief, Archives news Sep 1976 : 4-12.

Combrinck, J.A. Die SAW-Argief; Seksie Rekordbeheer, Archives news Sep 1976 : 13-22.

Digby, P.K.A. Historical records of the 8th South African Infantry, Militaria 7(1) 1977 : 57-65.

Grundlingh, A.M. Die rebellie van 1914; ' $n$ historiografiese verkenning, Kleio XI(1 \& 2) 1979 : 18-30.

Jacobs, C.J. Die problematiek in die navorsing van kontemporêre krygsgeskiedenis in SuidAfrika, Militaria 23(2) 1993 : 19-26.

Jacobs, F.J. SAW-Argief; Seksie Navorsing, Archives news Oct 1976 : 5-15.

Jonker, E. Die Militêr-Historiese en Argivale Dienste van die Departement van Verdediging, Militaria 1(1) $1969:$ 3-26.

Jooste, L. Delf in die geskiedenis, Paratus 44(6) Jun $1993: 41$.

Jooste, L. Die stand van Suid-Afrikaanse Militêre Geskiedskrywing oor die SA Weermag se betrokkenheid in Suidwes-Afrika en Angola, 1966 tot 1989, Militaria 23(2) $1993:$ 9-18.

Oberholzer, J.J. List of documents on early aviation in the collection of the National Museum, Bloemfontein, Militaria 3(6) $1973: 56$.

Perkins, Roger Regiments of the Empire; A Bibliography of their Published Histories. Newton
Abbot, Devon, 1989.

Pioeger, J. Suid-Afrikaanse staats- en staatsondersteunde militêre geskiedskrywing, 1924-1987, Militaria 19(4) 1989: 15-36.

Pretorius, C.M.L. Toeganklikheid van die SAWArgief, Archives news Oct 1989 : 34-37.

Van der Waag, I.J. "The Documentation Service Directorate (Military Archives): a concise history and summary of the archival holdings" in L. Botha (ed) : Archival Studies, Technicon Southern Africa, 1994.

Van der Waag, I.J. The Marriage of Clio and Mars; The practice of military history within the SA Defence Force. Military Archives Depot, Pretoria, 1992.

Van der Waag, I.J. Military Record Preservation in South Africa, 1914-1992; a history of Directorate Documentation Service, Militaria 23(4) 1993: 16-31.

Van der Waag, I.J. Military records as a genealogical source in South Africa, Familia; quarterly journal of the genealogical society of South Africa XXIX(4) 1992 : 74-77.

Van der Waag, I.J. Traces of a military trading organization; archives appertaining to the South African Defence Force Institute, South African archives journal 321990 : 54-64.

Visser, G.E. Die aard, studieveld en funksie van die Krygsgeskiedenis, Militaria 23(2) 1993 : 1 8.

\section{GENERAL}

Anon. Per aspera ad astra, 1920-1970; S.A. Air Force Golden Jubilee Souvenir Book. Pretoria, 1970.

Armstrong, R.F. The development of the S.A.A.F., 1920-1972, Paratus 24(3) March 1973 : 8-21.

Becker, D. On Wings of Eagles : South Africa's Military Aviation History. Durban, 1993.

Beinart, W. and C. Bundy Hidden Struggles in Rural South Africa; Politics \& Popular Movements in the Transkei \& Eastern Cape, 18901930. Johannesburg, 1987.

Bisset, W.M. South Africa's first anti-aircraft guns, Militaria 8(1) $1978: 22-23$.

Botha, H.J. and J. Ploeger Die Duitse aandeel in die militêre geskiedenis van Suid-Afrika en 
Suidwes-Afrika, Militaria 2(4) $1970: 1-25$. [also English and German translations : 26-72.]

Brits, A.(ed) A short history of the South African Army, South African defence force review 1991: 191-225.

Cock, Jacklyn Colonels \& Cadres; War \& Gender in South Africa. Cape Town, 1991.

Conradie, D. South Africa at War, 1912-1982, Militaria 12(2) $1982: 80-88$

Conradie, D. Achievements of the SADF, 19611982, Militaria 13(2) $1983: 51-56$.

Cornwell, R. South Africa and Imperial naval defence, Militaria 5(4) $1975: 29-43$.

Cross, I. Block houses and towers in South Africa, Soldiers of the queen 641991 : 8-10.

Cross, I. Block houses and towers in South Africa, part 2, Soldiers of the queen 651991 : 14-19.

Cross, I. Towers in South Africa, part 3, Soldiers of the queen 66 1991: 18-25.

Davidson, Basil The People's Cause; A History of Guerillas in Africa. Essex, U.K., 1981.

De la Rey, A.(ed) ' $n$ Kort Geskiedenis van die SA Vloot, South African defence force review 1989: 139-147. [also English trans - 'A short history of the SA Navy'.]

De la Rey, A.(ed) Kroniek van die SA Lugmag, 1920-1990, South African defence force review 1990 : 165-213. [also English trans - 'History of the SA Air Force, 1920-1990'.]

Dörning, W.A. A concise history of the South African Defence Force, 1912-1987, Militaria 17(2) $1987: 1-47$.

Du Toit, A. South Africa's Fighting Ships; Past and Present. Johannesburg, 1992.

Everson, G. Eastern Cape towers'and forts, Soldiers of the queen 68 1992: 12 .

Everson, G. Fort Willshire, Soldiers of the queen $631990: 31-32$.

Fisher, R.C. and J. Booysen Fortified frontier farmhouses; English precedent for the eastern Cape, South African journal of cultural history 8(1) : 1-12.

Fourie, Brand Buitelandse Woelinge om SuidAfrika, 1939-1985. Pretoria, n.d.
Frankel, Philip H. Pretoria's Praetorians. Cambridge, 1984.

Gerhardt, G.M. Black Power in South Africa; The Evolution of an Ideology. Berkeley, 1978.

Gleeson, lan The Unknown Force; Black, Indian and Coloured soldiers in two World Wars. Johannesburg, 1994.

Goosen, J.C. South Africa's Navy; The first fifty years. Cape Town and Johannesburg, 1973.

Gordon-Walker, P. The Commonwealth. London, 1962.

Grobler, Jackie A Decisive Clash? A short history of Black protest politics in South Africa, 1875-1976. Pretoria, 1988.

Grundlingh, A. Kleurlinge in militêre verband; Die funksie van gefabriseerde tradisie, 1912-1985, Kleio XVIII 1986 : 31-45.

Grundy, K.W. Soldiers without politics; Blacks in the South African armed forces. Berkeley, California 1983.

Heitman, H.R. and W.A. Dörning Still Champions; South African Defence Force, 1912-1987/ Steeds Kampioene; Suid-Afrikaanse Weermag, 1912-1987. Durban, 1987.

Hoods, W.R. The Cape Coloured Corps and the educational development of the Coloured people in South Africa, 1795-1977 (unpub D Phil, Wits 1983).

Hyam, R. The failure of South African expansion, 1908-1948. London, 1972.

Johnson, F.A. Defence by Committee; The British Committee of Imperial Defence, 1885-1959. London, 1960.

Jooste, L. Foreigners in the defence of South Africa, Militaria 16(1) $1986: 20-32$.

Karis, T. and G.M. Carter From Protest to Challenge; A Documentary History of African Politics in South Africa 1882-1964. Stanford, 19721977.

McCreath, S.N. Theirs is the Glory; SA Air Force Golden Jubilee Souvenir Book, 1920-1970. Johannesburg, 1970.

Meyer, C.M. Die rol van Swartes in die SuidAfrikaanse Weermag, 1912-1987, South African defence force review $1988: 281-329$. [also English trans - 'The Role of Blacks in the South African Defence Force, 1912-1987'.] 
Nöthling, C.J. Chiefs of the Union Defence Force/ South African Defence Force and Arms of Service, 1912-1990, South African defence force review 1991 : 63-75.

Nöthling, C.J. Kroniek van die Suid-Afrikaanse Geneeskundige Diens, 1913-1988, South African defence force review 1988 : 181-197. [also English trans - 'History of the South African Medical Service, 1913-1988'.]

Nöthling, C.J. Mylpale in die Geskiedenis van die SAW, 1912-1987, South African defence force review 1988 : 43-63. [also English trans - 'Milestones in the History of the SADF, 1912-1987'.]

Nöthling, C.J. and E.M. Meyers Kroniek van Diensplig in Suid-Afrika, South African defence force review 1990 : 255-287. [also English trans - 'Chronicle of Military Service in South Africa'.]

Ploeger, J. Hoofstukke uit die voor- en vroeë geskiedenis van die SAW, Militaria 1(3) 1969: 1-87.

Ploeger, J. Op Brandwag - drie eeue militêre geskiedenis van Suid-Afrika, Militaria 1(4) 1969: 4-47.

Ploeger, J. Suid-Afrika en die Imperiale Generale Stafgedagte, Militaria 3(2) 1972: 1-18.

Silburn, P.A. The Colonies and Imperial Defence. London, 1909.

Smith, H.H. Army, Air Force and Naval Colours and Flags in South Africa, 1652-1978 and the badges of the ships of the South African Navy. Grahamstown, 1980.

Smy, Ken South African Air Force, Air Pictorial Feb $1970: 46-57$.

Tomlinson, R. British blockhouses in the Pretoria area 1900-1902, Pretoriana 1041994 : 11-29.

Van den Bos, W.H. An investigation into resignation of Officers from the South African Air Force (Permanent Force) during the period 1946-1971 (unpub MA dissertation, UNISA, 1978).

Van der Waag, I.J. The Role of French Speakers in South African Military History, 1688-1988, South African defence force review 1988 : 253279. [also Afrikaans trans 'Die rol van Franssprekendes in die Suid-Afrikaanse Krygsgeskiedenis, 1688-1988'.]

Van der Waals, W.S. Die Weermag-attache - 'n studie in Internasionale Verhoudinge (unpub MA dissertation, UOVS 1970).
Walshe, P. The Rise of African Nationalism in South Africa. Berkeley, 1971.

Ward, E.H. Swifter than eagles; a brief history of the South African Air Force, 1912-1982, Militaria 12(2) $1982: 18-30$.

Wessels, A. Die Suid-Afrikaanse Vloot; verlede, hede, toekoms, deel 1, Militaria 11(3) 1981: 9-19.

Wessels, A. Die Suid-Afrikaanse Vloot; verlede, hede, toekoms, deel 2, Militaria 11(4) 1981: 1828.

\section{FORMATIVE YEARS}

Basson, N.F. Die geskiedenis van die Kaapse burgermag-mediese eenhede (unpub MA dissertation, US 1988).

Blamey, A.H.G. My Verulam Troop; Being a Short Account of the Verulam Troop of the Natal Mounted Rifles and of their Movements and Engagements when they were Seconded to the Durban Light Infantry in the Zulu Rebellion of 1906. Port Shepstone, n.d.

Curson, H.H. The Army Veterinary Services in South Africa, 1881-1914. Pretoria, 1938.

Curson, H.H. The Pre-Union forces of the Transvaal, 1852-1910. Pretoria, 1950.

Delius, P. The land belongs to us; The Pedi polity, the Boers and the British in the nineteenthcentury Transvaal. Johannesburg, 1983.

Grimbeek, C.L. Die Totstandkoming van die Unieverdedigingsmag, met spesifieke verwysing na die verdedigingswette van 1912 en 1922 (unpub D Phil thesis, UP 1985).

Guy, J. The destruction of the Zulu kingdom; The civil war in Zululand, 1879-1884. London, 1979.

Jacobs, C.J. Die rol van die Unieverdedigingsmag in die onderdrukking van die nywerheidsonluste van Januarie 1914, Militaria 18(4) 1988 : 48-51.

Jonker, E. Ontstaan en ontwikkeling van die Transvaalse Verdedigingsmag : Transvaal Volunteers, Militaria 3(3) $1972:$ 1-75.

Meyers, E.M. Voorgeskiedenis tot die stigting van ' $n$ Verdedigingsmag, Militaria 12(2) $1982: 1-6$.

Peires, J. The house of Phalo; A history of the Xhosa people in the days of their independence. Johannesburg, 1981.

Pietersen, S.J. Stakings aan die Witwatersrand, 
1913-1914 (unpub MA dissertation, UP 1970).

Ploeger, J. Suid-Afrikaanse Verdedigingskemas, 1887-1914, Militaria 1(5) $1969:$ 1-69.

Ploeger, J. Die Imperiale militêre beleid ten opsigte van Suid-Afrika, 1908-1910, Militaria 3(2) 1972: 19-29.

Omer-Cooper, J.D. The Zulu aftermath: A nineteenth century revolution in Bantu Africa. London, 1966.

Smit, J.P. Die Rol van Generaal J.H. de la Rey in die Suid-Afrikaanse Politiek, 1902-1914 (unpub MA dissertation, RAU 1974).

Stratford, D.O. Military Medical Services during the old Transvaal Republic, Military history journal 1(1) Dec $1967:$ 24-26.

Van den Bergh, G.N. Secret Service in the South African Republic, 1895-1900, Military history journal 3(2) Dec 1974 : 57-64.

\section{FIRST WORLD WAR}

Anon. Critical Study of the Campaign in Mesopotamia up to April 1917. Calcutta, 1925.

Anon. The German East African Campaign, 19141918, Military history journal 6(6) Dec 1985 : 192-199.

Adler, F.B.; A.E. Lorch and H.H. Curson The South African Field Artillery in German East Africa and Palestine, 1915-1919. Pretoria, 1958.

Bisset, W.M. Unexplored aspects of South Africa's First World War history, Militaria 6(3) 1976: 55-61.

Bouch, R.J. Medical Services in German South West Africa, Militaria 4(1) 1974 : 58-62.

Bouch, R.J. The railways and the war effort, 19141915, Militaria 4(4) $1974: 1-14$.

Bourquin, S. Heia Safari!, Military history journal 7(1) Jun $1986: 34-43$.

Brown, J. Ambrose They fought for King and Kaiser; South Africans in German East Africa, 1916. Johannesburg, 1991.

Brown, Malcolm The Imperial War Museum Book of the Western Front. London, 1993.

Bruwer, J.J. Kilometer 500; die beëindiging van die Suidwes-Afrika-kampanje 70 jaar gelede, Militaria 16(1) $1986:$ 4-13.

Buchan, J. The History of the South African Forces in France. London, 1920 (reprinted by the Imperial War Museum, London 1992).

Collyer, J.J. The Campaign in German South West Africa, 1914- 1915. Pretoria, 1937.

Collyer, J.J. The South Africans with General Smuts in German East Africa, 1916. Pretoria, 1939.

Cooper, F.H. Khaki Crusaders; With the South African Artillery in Egypt and Palestine. Cape Town, 1919.

Cornwell, R. The Sanusi Campaign, Militaria 5(1) $1975: 1-33$.

Cornwell, R. Delville Wood; the South Africans in France, April-July 1916, Militaria 7(2) 1977 : 155.

Desmore, A.J.B. With the Second Cape Corps thro' Central Africa. Cape Town, 1920.

Difford, I.D. The Story of the 1st Cape Corps, 1915-1919. Cape Town, c.1921.

Digby, P.K.A. Pyramids and Poppies; The 1st SA Infantry Brigade in Libya, France and Flanders, 1915-1919. Rivonia, 1993.

Greig, I.T. The Convoy System and the two Battles of the Atlantic, 1914-18 and 1939-45, Military history journal 6(4) Dec 1984 : 130-136.

Grundlingh, A.M. Die Suid-Afrikaanse Gekleurdes en die Eerste Wêreldoorlog (unpub D Litt et Phil thesis, UNISA 1981).

Grundlingh, A.M. Fighting Their Own War; South African Blacks and the First World War. Johannesburg, 1987.

Hordern, C. Military Operations in East Africa. London, 1941.

Keene, J.L. The Problem of Munitions Supply in the First World War and its Effect on the Union Defence Force, Military history journal 6(4) Dec 1984 : 123-129.

L'Ange, G. Urgent Imperial Service; South African forces in German South west Africa, 19141915. Rivonia, 1991.

Leipoldt, J.G.W. et $\mathrm{al}^{2}$ The Union of South Africa

2 This book was published anonymously, although the writer is known to have been Major J.G.W. Leipoldt. Lieutenant-Colonel Hon H.A. Wyndham and Brigadier General J.J. Collyer are also known to have had a hand in the manuscript. Collyer later produced his own two works on the South African forces in World War I. 
and the Great War 1914- 1918: Official History. Pretoria, 1924.

Lighthelm, J.H. Genl J.C.G. Kemp se rol in die Rebellie van 1914-15 (unpub MA dissertation, UP 1979).

Moller, P.W. Generaal C.F. Beyers se rol in die Rebellie van 1914 (unpub MA dissertation, UP 1976).

Nasson, B. A great divide; popular responses to the Great War in South Africa, War and society 12(1) 1994 : 47-64.

Nel, H.F. Die rol van die seemag in Duits SuidwesAfrika, 1914-1915, Militaria 7(2) 1977 : 56-65.

Nel, H.F. Toestande in die Unie van Suid-Afrika op die vooraand van die Eerste Wêreldoorlog, Militaria 16(3) 1986 : 24-31.

Nöthling, C.J. Suid-Afrika in die Eerste Wêreldoorlog, 1914-1918. Pretoria, 1994.

Ploeger, J. Die Zuid-Afrikaanse Vliegeniers Korps; vliegtuie en personeel vir en in Suidwes, 19141915, Militaria 2(1) $1970:$ 26-67.

Ploeger, J. The South African Field Post and Telegraph Corps, 1914-1915, Militaria 2(5) 1970 : 1-73.

Ritchie, Moore With Botha in the Field. London, 1915.

Stemmet, F.J. Die Geskiedenis van die SuidAfrikaanse Artillerie, 1912-1918 (unpub D Phil thesis, RAU 1985).

Trew, H.F. Botha Treks. London and Glasgow, 1937.

Uys, I. Delville Wood. Johannesburg, 1983.

Uys, I. Rollcall; The Delville Wood Story. Johannesburg, 1991.

Uys, I. The Lessons of Delville Wood, Military history journal 6(1) Jun 1983 : 16-21.

Uys, I. The South Africans at Delville Wood, Military history journal 7(2) Dec 1986 : 45-58.

Van der Waag, I.J. Major J.G.W. Leipoldt, D.S.O.: A portrait of a South African surveyor and intelligence officer, 1913-1923, Militaria 24(3) 1994: 12-34.

Van Jaarsveldt, A.E. Die Rol van die SuidAfrikaanse Militêre Geneeskundige Diens in die
Suidwes-Afrika-veldtog, 1914-15 (unpub MA dissertation, UP 1983).

Van Jaarsveldt, A.E. Militêre Geneeskunde gedurende die vroeë jare, deel 2, Militaria 7(1) $1977: 24-44$.

Van Jaarsveldt, A.E. Die Suid-Afrikaanse Militêre Verplegingsdiens, Militaria 8(2) $1978: 56-66$.

Van Zyl, A.E. Militêre Geneeskunde gedurende die vroeë jare, deel 1, Militaria 6(4) 1976: 1-14.

War Office Statistics of the Military Effort of the British Empire during the Great War, 1914-1920. London, 1922.

Wavell, A.P. The Palestine Campaigns. London, 1941.

Woodward, D.R. The Imperial Strategist; Jan Christiaan Smuts and British Military Policy, 1917-1918, Military history journal 5(4) Dec 1981: 131-145, 148, 153.

\section{THE INTERWAR YEARS 1919-} 1939

Beinart, William "Amafelandawonye (The Die Hards); Popular portest and women's movements in Herschel district in the 1920s" in Beinart and Bundy : Hidden Struggles in Rural South Africa (Johannesburg, 1987).

Bisset, W.M. South Africa's role in the Civil War in Russia, 1918-1920, Militaria 15(4) 1985 : 4648.

Carter, G.M. The British Commonwealth and International Security; The Role of the Dominions, 1919-1939. Westport, 1971.

Clayton, A. The British Empire as a Superpower, 1919-1939. Basingstoke and London, 1986.

Cockbain, T.G.E. Early history of Aviation in the Eastern Province, Militaria 24(1) 1994 : 44-48.

Edgar, Robert The Fifth Seal; Enoch Mgijima, the Israelites and the Bulhoek Massacre, 1921 (unpub PhD thesis, University of California, 1977.

Holland, R.F. Britain and the Commonwealth Alliance, 1918-1939. London, 1981.

Klopper, I.H.S. Die Funksionering en militêre opbou van die Suid-Afrikaanse Lugmag binne die Unieverdedigingsmag, 1934-1939 ter voorbereiding van oorlog (ms n.d.). 
Mansergh, N. Survey of British Commonwealth Affairs; Problems of External Policy, 1931-1939. London, 1952.

Oberholster, A.G. Die Randse Staking van 1922 (Unpub D Phil thesis, UP 1979).

Van der Waag, I.J. South Africa and the War in Asia Minor, 1921-1923, Militaria 24(1) 1994: 9-19.

Van der Waag, I.J. Twenty Years' Armistice, 19191939; The Union Defence Force between the Wars (ms, Military Archives Depot, Pretoria, 1993).

Van Wyk, J. Die Unieverdedigingsmagte op die vooraand van die Tweede Wêreldoorlog, 19341939, Militaria 6(4) $1976: 24-32$.

\section{SECOND WORLD WAR}

Agar-Hamilton, J.A.I. and L.C.F. Turner Crisis in the Desert, May-July 1942. Cape Town, 1952.

Agar-Hamilton, J.A.I. and L.C.F. Turner The Sidi Rezegh Battles, 1941. London, 1957.

Anon. A Bank in Battledress; Being the Story of Barclays Bank (Dominion, Colonial and Overseas) during the Second World War, 1939-45. Cape Town, 1948.

Anon. Campaigns in the Western Desert and North Africa: 1st and 2nd Divisions, Nov 1941 to May 1943 (ms, Military Archives Depot, Pretoria, n.d.).

Anon. The East African Campaign: SA Forces, July 1940 to July 1941 (ms, Military Archives Depot, Pretoria, n.d.).

Anon. The History of the South African Veterinary Corps (Veterinary and remount Services) 19391946 , including the History of the Directorate of Remounts, 1940-42 (ms, Military Archives Depot, Pretoria, 1946).

Anon. A Record of the Organisation of the Director-General of War Supplies (1939-1943) and Director-General of Supplies (1943-1945). Johannesburg, n.d.

Anon. South African Forces in the Second World War, Militaria 19(3) 1989, pp.22-48.

Anon. The 2nd South African Division's Operations on the Libyan-Egyptian Frontier, 5 December 1941-17 January 1942 (ms, Military Archives Depot, Pretoria 1952).

Anon. We Fought The Miles; the history of the
South African Railways at war, 1939-1945. n.p., n.d.

Aquadro, C.F. A POW's story, Militaria 19(3) 1989: $1-10$.

Axelson, E.V. The South African Air Force in North Africa, parts I-IV (ms, Union War Histories Section, Pretoria n.d.).

Ball, J.A. Italian Prisoners of War in South Africa, 1941-1947, Military history journal 1(1) Dec $1967: 21-23$.

Bauer, C. German strategic and tactical use of submarines in both world wars, Journal for contemporary history June 1989.

Becker, D. Yellow Wings; the story of the Joint Air Training Scheme in World War II. Pretoria, 1988.

Bird, M.E. and M. Botes Flying High; The story of the Womens' Auxiliary Air Force, 1939-1945, Military history journal5(5) Jun 1982 : 172-177.

Birkby, C. Springbok Victory. Cape Town, 1941.

Bisset, W.M. South African naval personnel seconded to the Royal navy during the Second World War, 1939-1945, Militaria 12(1) 1982 : 10-26.

Bisset, W.M. South African naval personnel seconded to the Royal Navy, 1940-1942, Militaria 15(1) $1985: 59-61$.

Bisset, W.M. South Africa's D-Day Veterans, Militaria 24(2) 1994 : 10-14.

Blumberg, L. Italian P.O.W. in South Africa - Medical Services, Military history journal 1(4) Jun $1969: 15-18$.

Bouch, R.J. 6 SA Armoured Division in Italy, Militaria 4(2) $1974: 47-64$.

Bouch, R.J. 6 SA Armoured Division in Italy, Militaria 4(3) 1974 : 58-73.

Bouch, R.J. The railways and the war effort, 19391945, Militaria 5(2) $1975: 66-75$.

Breedt, J.v.d.B. Die Suid-Afrikaanse oorlogsekonomie gedurende die Tweede Wêreldoorlog, deel 1, Militaria 13(1) $1983:$ 46-66.

Breedt, J.v.d.B. Die Suid-Afrikaanse oorlogsekonomie gedurende die Tweede Wêreldoorlog, deel 2, Militaria 13(2) $1983:$ 1-18.

Broodryk, M. and P.W. Coetzer Die invloed van 
die Tweede Wêreldoorlog op Suid-Afrikaanse algemene verkiesings, Journal for contemporary history 18(1) $1993:$ : 93-112.

Brown, D.D. The Brew goes on; The story of 'the Blower' in Italian POW Camps, Military history journal 8(6) Dec 1991: 199-200.

Brown, J. Ambrose A Gathering of Eagles; the campaigns of the South African Air Force in Italian East Africa, June 1940 - November 1941, with an introduction 1912-1939. Cape Town, Johannesburg and London, 1970.

Brown, J. Ambrose Eagles Strike; the campaigns of the South African Air Force in Egypt, Cyrenaica, Libya, Tunisia, Tripolitania and Madagascar, 1941-1943. Cape Town, Johannesburg and London, 1974.

Brown, J. Ambrose The War of a Hundred Days; Springboks in Somalia and Abyssinia, 1940-41. Johannesburg, 1990.

Brown, J. Ambrose Retreat to Victory; A Springbok's diary in North Africa: Gazala to El Alamein, 1942. Johannesburg, 1991.

Bruwer, J.J. Die rol van die Sesde Suid-Afrikaanse Pantserdivisie in die ontplooiing van die Geallieerde offensief in Italië: Die slag van Monte Stanco, 7 tot 13 Oktober 1944 (unpub MA dissertation, RAU 1979).

Cooper, F.W. The Police Brigade; 6th SA Infantry Brigade, 1939-1945. Cape Town, 1972.

Cornwell, R. 2 Anti-Tank Regiment, SAA - tank and anti-tank in the Western Desert, 1940-1942, part 1, Militaria 6(1) $1976: 37-51$.

Cornwell, R. 2 Anti-Tank Regiment, SAA - tank and anti-tank in the Western Desert, 1940-1942, part 2, Militaria 6(2) $1976:$ 49-71.

Cornwell, R. 2 Anti-Tank Regiment, SAA - tank and anti-tank in the Western Desert, 1940-1942, part 3, Militaria 6(3) $1976:$ 24-48.

Cornwell, R. 2 Anti-Tank Regiment, SAA - tank and anti-tank in the Western Desert, 1940-1942, part 4, Militaria 6(4) 1976 : 33-61.

Cornwell, R. South African armoured car production in World War 2, Militaria 7(3) 1977 : 30-41.

Cowin, J.N. The Story of the Ninth; A Record of the 9th Field Company South African Engineer Corps, July 1939 to July 1943. Johannesburg, n.d.
Cowling, N.M.(ed) Historical Survey of the NonEuropean Army Services (NEAS) outside of the Union of South Africa (Part I), Militaria 24(1) 1994 : 28-43.

Cowling, N.M.(ed) Historical Survey of the NonEuropean Army Services (NEAS) outside of the Union of South Africa (Part II), Militaria 24(2) 1994 : 30-39.

Cowling, N.M. Operation Overlord - A synopsis of the D-Day landings, Militaria 24(2) 1994 : 5-9.

Crook, L. Non-White Personnel in the South African Artillery, 1939-1945, and today, Militaria 24(2) 1994 : 15-29.

Crwys-Williams, J. A Country at War, 1939-1945; The Mood of a Nation. Rivonia, 1992.

Curson, H.H. History of the South African Veterinary Corps (veterinary and remount services), 1939-1946; including the history of Directorate of Remounts, 1940-1942. Pretoria, 1946.

Ellis, John The World War II Databook; The Essential Facts and Figures for All the Combatants. Bodmin, 1993.

Fourie, D.F.S. Operation Rose - The only amphibious landing by South African Forces at war Madagascar, 1942, Military history journal 2(1) Jun 1971: 15-18, 37.

Gibbs, K.J. Demobilisation after World War II; The Process and Politics of Reinstating Union Defence Force Volunteers into Civilian Life, 19431948 (unpub BA Hons paper, UNISA 1990).

Greig, I.T. The Convoy System and the two Battles of the Atlantic, 1914-18 and 1939-45, Military history journal 6(4) Dec 1984 : 130-136.

Grobler, J.E.H. Die Geallieerde besetting van Madagascar in 1942, met spesifieke verwysing na die rol van die Unieverdedigingsmag in die operasies, deel 1, Militaria 7(4) 1977 : 1-18.

Grobler, J.E.H. Die Geallieerde besetting van Madagascar in 1942, deel 2: die konsolidasietydperk Mei-Augustus 1942, Militaria 8(1) 1978 : 39-54.

Grobler, J.E.H. Die Geallieerde besetting van Madagascar in 1942, deel 3: die toetrede van die Suid-Afrikaanse landmagte en die besetting van Tananarive, Militaria 8(2) 1978 : 15-40.

Grobler, J.E.H. Die Geallieerde besetting van Madagascar in 1942, deel 4: Tamatave, Tulear, 
en die oorgawe van Annet, Militaria 8(3) 1978 : $52-72$.

Grobler, J.E.H. Die Geallieerde besetting van Madagascar in 1942, deel 5: die lugoffensief, mediese aspekte en Vry Franse oorname, Militaria 8(4) 1978 : 69-76.

Groenewald, A.J. 'n Kritiese ontleding van die faktore wat gelei het tot die oorgawe van die Suid-Afrikaanse magte by die slag van Tobruk (unpub D Phil thesis, UOVS 1991).

Grundlingh, L. Soldiers and Politics; A study of the political consciousness of black South African soldiers during and after the Second World War, Historia 36(2) 1991 : 55-66.

Grundlingh, L.W.F. Loyalties, prejudices and promises; a study of changing attitudes regarding the participation of South African blacks in the Second World War, Journal of contemporary history December 1989.

Grundlingh, L.W.F. 'Non-Europeans should be kept away from the towns'; Controlling black South African soldiers during the Second World War, International journal of historical studies 25(3) $1992:$ 539-560.

Grundlingh, L.W.F. The participation of South African Blacks in the Second World War (unpub D Phil, RAU 1987).

Harris, C.J. War at Sea; South African Maritime Operations during World War II. Rivonia, 1991.

Hewitt, F.J. South Africa's role in the development and use of Radar in World War II, Military history journal 3(3) Jun $1975: 88-92,103$.

IIIsley, J.W. The Weak Link that Held; a study of wartime official and semi-official propaganda in South Africa, 1939-1942 (unpub BA Hons paper, Univ Wits 1985).

Isemonger, L. Target Warsaw; the story of South Africa's first heavy bomber squadron (unpub ms, 1974).

Jacobs, C.J. 'n Evaluering van die rol van die Eerste Suid-Afrikaanse Infanteriedivisie tydens die eerste slag van El Alamein, 1-30 Julie 1942 (unpub MA dissertation, US 1988).

Jacobs, C.J. and G. Pool Die rol van die Eerste Suid-Afrikaanse Infanteriedivisie tydens die eerste slag van El Alamein, 1-30 Julie 1942, Historia 36(2) $1991: 31-54$.

Jacobs, F.J. 6 SA Armoured Division in Italy, Militaria 4(2) 1974 : 47-64.
Jacobs, F.J. 6 SA Armoured Division in Italy, Militaria 4(3) 1974 : 58-73.

Jacobs, F.J. 4 Field Regiment in East Africa, 19391941, Militaria 4(4) $1974: 48-57$.

Jacobs, F.J. Anti-Aircraft Artillery in the Second World War, Militaria 7(1) $1977:$ 8-17.

Keene, John (ed) South Africa in World War II; A pictorial history. Cape Town, Johannesburg and Pretoria, 1995

Killingray, D. and R. Rathbone Africa and the Second World War. Basingstoke, 1986.

Klein, H. Springboks in Armour; the South African Armoured Cars in World War II. Cape Town and Johannesburg, 1965.

Kros, J. War in Italy; With the South Africans from Taranto to the Alps. Rivonia, 1992.

Kruger, C. Italiaanse Krygsgevangenes in die Zonderwaterkamp, Suid-Afrika, 1941-1947 (unpub BA Hons paper, UP 1991).

Lamb, Richard War in Italy, 1943-1945; A Brutal Story. London, 1993.

Leigh, M. Captives Courageous; South African Prisoners of War, World War II. Johannesburg, 1992.

Loraine-Grews, J.E. Union Defence Forces; Statistics of the wounded and prisoners of war during the Second World War, Militaria 15(1) 1985: 62.

Mahncke, J.O.E.O. Tobruk - 1942; Compiled and translated from the official war diary of the German Supreme Command, Military history journal 7(6) Dec 1988 : 234-235.

Mansergh, N. Survey of British Commonwealth Affairs; Problems of Wartime Co-operation and Post-War Change, 1939-1952. London, 1952.

Martin, H.J. and N. Orpen Eagles Victorious; The Operations of the South African Forces over the Mediterranean and Europe, in Italy, the Balkans and the Aegean, and from Gibraltar and West Africa. Cape Town, Johannesburg and London, 1977.

Martin, H.J. and N. Orpen South Africa at War; Military and Industrial Organization and Operations in connection with the conduct of the war, 1939-1945. Cape Town, Johannesburg and London, 1979. 
Moller, P.L. 31 Eskader en 34 Eskader SuidAfrikaanse Lugmag se aandeel aan die Warskou-operasies gedurende Augustus en September 1944 (unpub MA dissertation, US 1985).

Monick, S. and O.E.F. Baker Mega, February 1941; The role of the 1st South African Irish Regiment, Militaria 20(4) $1990:$ 27-53.

Newman, J.H. and A.G. Vosloo 6th Battery, Natal Field Artillery, S.A.A.: A Saga of Gunners in the Western Desert, 12th August 1941-13 June 1942. Cape Town, 1990.

North, J.W. South African Army Postal Services, 1940-1946, Militaria 2(6) $1970:$ 1-51.

Oosthuizen, F. Changes and Expectations : The White Union Defence Force soldier prior to and during the Second World War, Militaria 23(3) $1993: 32-42$.

Oosthuizen, F. Demobilisation and the Post-War Employment of the White Union Defence Forces soldier, Militaria 23(4) 1993 : 32-38.

Oosthuizen, F. Soldiers and Politics : The political ramifications of the White Union Defence Force soldiers' demobilisation experience after the Second World War, Militaria 24(1) 1994 : 20-27.

Orpen, N. East African and Abyssinian Campaigns. Cape Town and Johannesburg, 1968.

Orpen, N.D. S.A. Coloured and Indian Soldiers in World War II - A Comment, South Africa international 11(3) 1981.

Orpen, N. Victory in Italy. Cape Town and Johannesburg, 1975.

Orpen, N. War in the Desert. Cape Town and Johannesburg, 1971.

Orpen, N. and H.J. Martin Salute the Sappers, Part 1; The formation of the South African Engineers Corps and its operations in East Africa and the Middle east to Battle of Alamein. Johannesburg, 1981.

Orpen, N. and H.J. Martin Salute the Sappers, Part 2; The operations of the South African Engineers Corps in the North African and Italian theatres of war from the Battle of El Alamein to the end of World War II, with a brief description of subsequent developments. Johannesburg, 1982.
Pienaar, E. Enkele Ekonomiese aspekte van die voorsiening van krygsvoorrade aan die Unieverdedigingsmag met spesiale verwysing na die produksie van krygsvoorrade in die Unie van Suid-Afrika gedurende Wêreldoorlog II, 1939 tot 1945 (unpub D Comm thesis, UP 1964).

Ploeger, J. Notes on the 6th South African Armoured Division Postal Unit, Militaria 2(6) 1970: 69-74.

Rosenthal, Eric et al South African Jews in World War II. South African Jewish Board of Deputies, Johannesburg, 1950.

Rosignoli, G. The Allied Forces in Italy, 1943-45. Newton Abbot, 1989.

Smith, G.B. U.S. Naval intelligence and South Africa, 1941-45, Journal for contemporary history Mar 1978

Steenkamp, W.P. Some medical impressions of Abyssinia, Militaria 4(3) 1974 : 28-35.

Tidy, D.P. Dodecanese Disaster and the Battle of Simi - 1943, Military history journal 1(2) Jun 1968 : 16-21.

Tothill, F.D. The 1943 General Election (unpub MA dissertation, UNISA 1987).

Tungay, R.W. The Fighting Third. Cape Town, n.d.

Turner, L.C.F., H.R. Gordon-Cumming and J.E. Betzler War in the Southern Oceans, 19391945. London, 1961.

Van der Waag, I.J. Allied Military Currency of the Second World War; a study in emergency paper money, Militaria 23(2) 1993 : 28-43.

Van der Waag, I.J. and N.M. Cowling Victory in Europe, 8 May 1945, Salut 2(5) May 1995 : 5455.

Van der Waag-Cowling, Noëlle That mushroom cloud - 50 years later, Salut 2(9) Sep 1995, pp.46-48.

Van Eyssen, J.L. The Warsaw Airlift, Military history journal 6(2) Dec $1983:$ 37-40.

Vlok, T.C.B. The application of radar in the UDF during World War 2, Militaria 4(2) 1974: 13-17.

Wandrag, N. Die rol van die Suid-Afrikaanse Lugmag in die bomwerper-vegvliegtuie-taktiek 
van die Geallieerde Lugmag in Noord-Afrika, 1941-43 (unpub MA dissertation, UP 1981).

Wandrag, N. ' $n$ Kritiese evaluering van die SuidAfrikaanse Lugmag in die Tweede Wêreldoorlog (unpub D Phil thesis, UP 1987).

Welding, S.M. Die Geskiedenis van die VroueLandmag Hulpdiens gedurende die Tweede Wêreldoorlog (unpub MA dissertation, UP 1990).

Wessels, A. Die opbou van die Unieverdedigingsmagte in die tydperk September 1939 tot 1941, Journal for contemporary history 19(3) $1994: 1-22$.

\section{AFRICAN DEFENCE, THE COMMONWEALTH AND THE COLD WAR}

Anon. Korea - 25 Years; SADF Soldiers Remember, Paratus 29(7) Jul 1978.

Barber, J. South Africa's Foreign Policy, 1945 1970. London, New York and Cape Town, 1973.

Barclay, C.N. The First Commonwealth Division; the story of British Commonwealth land forces in Korea, 1950-1953. Aldershot, 1954.

Baylis, J. Anglo-American Defence Relations, 1939-1984; The Special Relationship. Macmillan, 1984.

Berridge, G.R. The Diplomacy of the Veld; Charles te Water and the 'Organic Approach' to South African Foreign Policy, International relations 10(1) May 1990.

Berridge, G.R. Economic Power in Anglo-South African Diplomacy; Simonstown, Sharpeville and After. London and Basingstoke, 1981.

Berridge, G.R. The Ethnic 'Agent in Place': English-speaking Civil Servants and Nationalist South Africa, 1948-1957, Intelligence and national security 4(2) Apr 1989 : 257-267.

Berridge, G.R. South Africa, the Colonial Powers and 'African Defence'; The Rise and Fall of the White Entente, 1948-60. Basingstoke, 1992.

Borstelmann, Thomas Apartheid's Reluctant Uncle; The United States and Southern Africa in the Early Cold War. New York and Oxford, 1993.

Buchan, Alastair 'Commonwealth Military Relations', in W.B. Hamilton, K. Robinson and C.D.W.
Goodwin (eds) A Decade of the Commonwealth, 1955-1964. Durham N.C., 1966.

Carew, T. Korea; The Commonwealth at War. London, 1967.

Coker, C. NATO, The Warsaw Pact and Africa. Basingstoke (Macmillan), 1985.

Dale, R. The South African Armed Forces and their link with the United Kingdom and the Commonwealth of Nations, 1910-1961, Militaria 9(1) $1979: 1-11$

De Beer, K.J. Dr D.F. Malan's diplomacy as Minister of Foreign Affairs, 1948-1954, Journal for contemporary history Dec 1984.

Dockrill, M. British Defence since 1945. Oxford and New York, 1988.

Dockrill, M. and J.Young (eds) British Security Policy, 1945-56. Basingstoke and London : Macmillan, 1988.

Garner, J. The Commonwealth Office, 1925-1968. London, 1978.

Geldenhuys, D. The South African National Party and the British Government, 1939-1961, Politikon 5(1) Jun 1978.

Geldenhuys, D.J. The politics of race; a study of the impact of South Africa's general election of 1948 on Anglo-South African relations, Journal for contemporary history Mar 1979.

Geyser, O. The visit of British Premier Harold Macmillan to Africa in the year 1960, Journal for contemporary history Oct 1990.

Giangreco, D.M. and R.E. Griffin Airbridge to Berlin; The Berlin Crisis of 1948, its origins and aftermath. Presidio Press, 1988.

Grey, J. The Commonwealth armies and the Korean War; An alliance study. Manchester and New York, 1988.

Hastings, Max The Korean War. London, 1987.

Henshaw, P.J. The transfer of Simonstown; Afrikaner nationalism, South African strategic dependence and British global power, Journal of imperial and commonwealth history 20(3) 1992 : 419-444.

Labuscagne, G.S. Suid-Afrika en Afrika; die staatkundige verhouding in die tydperk 19451966. Potchefstroom, 1969. 
Mansergh, N. Documents and speeches on British Commonwealth affairs, 1931-1952. London, 1953.

Mansergh, N. Documents and speeches on British Commonwealth affairs, 1952-1962. London, 1963.

Mansergh, N. Survey of British Commonwealth affairs; Problems of Wartime Co-operation and Post-War Change, 1939-1952. London, New York and Toronto, 1958.

Mansergh, N. The Commonwealth Experience. London, 1969.

McGregor, P.M.J. The History of No 2 Squadron, SAAF, in the Korean War, Military history journal 4(3) Jun 1978.

Moore, D.M. SAAF in Korea, Militaria 10(4) 1980: 24-34.

Moore, D.M. The Role of the South African Air Force in the Korean War, 1950-1953 (Unpub D Litt et Phil thesis, UNISA 1982).

Moore, D.M. The South African Air Force in Korea; an assessment, Military history journal6(3) Jun $1984: 88-94$.

Moore, D.M. and P. Bagshawe South Africa's Flying Cheetahs in Korea. Johannesburg, 1991.

Orpen, N.D. The history of NATO and the Warsaw Pact, Military history journal 1(6) Jun 1970: 21-24, 38.

Ovendale, R. The South African Policy of the British Labour Government, 1947-51, International affairs 59(1) Winter 1982/3.

Parsons, Anthony From Cold War to Hot Peace; UN Intervention, 1947-1994. London, 1995.

Spence, J.E. Republic under pressure; a study of South African foreign policy. London, 1965.

Spence, J.E. The Strategic Significance of Southern Africa. Royal United Services Institutions, 1970.

Stuart, D.T.(ed) Politics and Security in the Southern Region of the Atlantic Alliance. Macmillan, 1987.

Taylor, D. The years of challenge; the Commonwealth and the British Empire, 1945-1958. London, 1959.

Van der Waag, I.J. (ed) Lieutenant General J.R.
Dutton; personal aspects of the Korean war, 1952-1953. [mss, Military Archives Depot, Pretoria, 1992].

Van der Waag, I.J. The Korean War; 40 years since the signing of the Armistice, Paratus 44(8) Aug 1993 : 22-23.

Van der Waag, I.J., J.R. Dutton and N.M. Cowling Action in Korea; The story of the South African Army officers, 1950-1953. Pretoria : Military Archives Depot, 1993.

Van der Waag, I.J. and N.M. Cowling Airlift to Berlin, Paratus 44(10) Oct 1993 : 24-25.

Wilkinson, P. The Defence of the West. Macmillan, 1988.

Young, A.D.T. British relations with South Africa since unification (unpub $\mathrm{Ph} \mathrm{D}$ thesis, Univ. of Bristol, 1975).

\section{CONSOLIDATION, PROTEST AND LIBERATION}

Amokpasa, B. Heroes of the Sharpeville tragedy. Johannesburg, 1961.

Barclay, G.St.J. Strategy of despair; South Africa and the alignment of the alienated, 1974-1982, Journal for contemporary history Dec 1982.

Botha, P.W. Die plek van Suid-Afrika in die internasionale magskonstellasies, Journal for contemporary history Sep 1977.

Christopher, A.J. The pattern of diplomatic sanctions against South Africa, 1948-1994, GeoJournal 34(4) 1994 : 439-46.

Cock, Jacklyn and Laurie Nathan (eds) War and Society; The militarisation of South Africa. Cape Town and Johannesburg, 1989.

Coetzer, P.W. Relations between South Africa and the Soviet bloc, Journal for contemporary history 16(2) $1991: 23-44$.

Davis, S.M. Apartheid's Rebels; Inside South Africa's Hidden War. New Haven and London, 1987.

Davis, S.M. Season of War; Insurgency in South Africa, 1977-80 (Ph.D. diss., Fletcher School of Law and Diplomacy, Tufts University, 1982).

Ellis, S. Mbokodo; security in ANC camps, 19611990, African affairs; journal of the Royal African Society 93(371) : 279-98. 
Feit, E. Urban Revolt in South Africa, 1960-1964. Evanston, 1971.

Gann, L.H. and P. Duignan South Africa; War, Revolution or Peace. Stanford, 1978.

Grundy, K.W. A Black Foreign Legion in South Africa?, African affairs 80(318) Jan 1981.

Gutteridge, W. The military in South African politics; champions of national unity?, Conflict studies 2711994 : entire issue.

Heitman, H.R. South African War Machine. Johannesburg, 1985.

Heitman, H.R. South African Armed Forces. Cape Town, 1990.

Henshaw, P.J. Britain and South Africa at the United Nations; 'South West Africa', 'treatment of Indians' and 'race conflict', 1946-1961, South African historical journal 31 1994: 80-102.

Howe, H.M. The South African Defence Force and political reform, Journal of modern African studies 32(1) 1994 : 29-51.

Jaster, Robert S. South Africa's Narrowing Security Options, Adelphi papers 159 Spring 1980.

Johns, S. Obstacles to Guerilla Warfare - A South African case study, Journal of modern African studies 2(2) 1973.

Kagambe, D. Revolutionary theory and model for guerilla action in the non-liberated African territories. Washington, 1970.

Kane-Berman, J. Soweto; Black Revolt, White Reaction. Johannesburg, 1978.

Karis, Thomas South African Liberation; The Communist Factor, Foreign affairs Winter 1986/87.

Klare, M.T. and E. Prokosch Evading the Embargo; How the U.S. arms South Africa and Rhodesia, Notes and documents (U.N. Centre Against Apartheid) 34/78 Oct 1978.

Leonard, Richard South Africa at War; White Power and the Crisis in Southern Africa. Westport, 1983.

Le Roux, C.J.B. The ANC-SACP's Political Military Council; a brief profile of its origin and leadership, Journal for contemporary history 19(1) 1994 : 143-93.

Le Roux, C.J.B. Umkhonto we Sizwe's Military High Command $(\mathrm{HC})$; a profile of its exile lead- ership in the late 1980s, Journal for contemporary history 19(3) 1994 : 152-73.

Lodge, T. Black Politics in South Africa since 1945. Johannesburg, 1983.

Luthuli, A. Let my people go. London, 1962.

Mashabela, H. A people on the Boil; Reflections on Soweto. Johannesburg, 1987.

Mbeki, Govan South Africa; The Peasants' Revolt. N.p., 1984.

Mbeki, Govan The Struggle for Liberation in South Africa; A Short History. Cape Town, 1992.

McWilliams, J.P. The arms embargo against South Africa; success or futility?, Journal for contemporary history Jun 1988.

Mexer D. and G. (eds) From shantytown to forest; Life histories from the revolution: South Africa ANC 1: Story of Norman Duke. Richmond, Canada, 1974.

Mothlabi, M. Black resistance to Apartheid. Johannesburg, 1984.

Mtolo, B. Umkonto we Sizwe; The road to the left. Durban, 1966.

Ngubo, A. The development of African political protest in South Africa, 1882-1910; An analytical approach (unpub $\mathrm{PhD}$ thesis, University of California, 1973).

Tambo, O. "Passive resistance in South Africa", in J.A. Davis and J.K. Baker: Southern Africa in transition (New York, 1966).

Wheeler, J.P. ' $n$ Bydrae gelewer tot die ontwerp van moderne wapenstelsels met verwysing na inisiëringselemente (unpub D Sc thesis, PU for CHE 1980).

\section{SOUTHERN AFRICA WAR 1966-1989}

Anon. Die SAW se rol in SWA, Militaria 14(1) 1984: 37-41.

Ackerman, F.S.J. Die Kubane in Angola; Probleme ten spyt, Journal for contemporary history Dec 1987.

Barnard, L.D. Angola in die internasionale magskonstellasies, Journal for contemporary history Mar 1977.

Barnard, S.L. 'n Historiese oorsig van die 
gewapende konflik aan die noordgrens van SWA/Namibië, 1966-1989, Acta academica 23(1) $1991: 102-127$.

Breytenbach, J. Forged in Battle. Cape Town, 1986.

Breytenbach, J. They Live By The Sword; 32 'Buffalo' Battalion - South Africa's Foreign Legion. Alberton, 1990.

Bridgland, Fred Jonas Savimbi; A Key to Africa. Edinburgh, 1986.

Bridgland, Fred The War for Africa; Twelve Months that Transformed a Continent. Gibraltar, 1990.

Brown, B. South Africa's Foreign Policy toward Its Black Neighbors (unpub Ph.D. diss., Boston University, 1979).

Cawthra, Gavin Brutal Force; The Apartheid War Machine. London, 1986.

Coccia, Gianarlo The Scorpion Sting; Moçambique. Johannesburg, 1976.

Coetzer, P.W. Suidwes-Afrika/Namibië - op pad na ' $n$ nuwe toekoms, Journal for contemporary history Dec 1988.

Dale, Richard The armed forces as an instrument of South African policy in Namibia, Journal of modern African studies 18(1) 1980 : 57-71.

Dale, Richard 'Botswana as a Hostage to High Politics? Twentieth Century Conflict with South Africa and Zimbabwe' in Stephen John Stedman (ed) : Botswana; The Political Economy of Democratic Development. Boulder and London, 1993.

Dale, Richard Welding war and politics in Namibia; South Africa's counterinsurgency campaign, 1966-1989, Armed forces and society 20(1) $1993: 7-24$.

Dale, Richard The Politics of national Security in Botswana, 1900-1990, Journal of contemporary African studies 12(1) 1993 : 40-56.

De Beer, K.J. Die veelpartykonferensie in Geneve oor Suidwes-Afrika/Namibië, Januarie 1981, Journal for contemporary history Jul 1981.

De Beer, K.J. Die breër betekenis van die mislukte militere inligtingsoperasie in Angola, Journal for contemporary history Aug 1985.
De Beer, K.J. SWA/Namibia - Detente with Russia?, Journal for contemporary history Apr 1985.

De Beer, K.J. Focus on Mozambique, Journal for contemporary history Dec 1986.

De Klerk, P. Die Walvisbaai-enklawe; 'n koloniale oorblyfsel?, Journat for contemporary history Dec 1990.

Dempsey, M.C. Die militêre konflik tussen die SuidAfrikaanse magte en SWAPO in die operasionele gebied, 1974-1980 (unpub MA dissertation, UOVS 1984).

De Vries, W. van W. Die South West African Peoples' Organisation (unpub MA dissertation, UP 1980).

Dörning, W.A. A historical analysis of the military strategic implications for the Republic of South Africa of Unita's activities in Angola, 1976-1983 (unpub D Phil thesis, UOVS 1987).

Dörning, W.A. and H.R.Heitman The Joint Monitoring Commission, Militaria 18(1) 1988: 1-27.

Dugard, John (ed) The South West Africa/Namibia Dispute: Documents and scholarly writings on the controversy between South Africa and the United Nations. Berkeley and London, 1973.

Du Pisani, André SWA/Namibia; The Politics of Continuity. Johannesburg, 1986.

Du Plessis, T.A.P. Die ontwikkeling van die SWA Weermag, Militaria 13(1) $1983: 28-34$.

Du Preez, S. Avontuur in Angola; die verhaal van Suid-Afrika se soldate in Angola 1975-1976. Pretoria, 1989.

Du Preez, S. Operasie Savannah; Dagboek van kaptein J.A. Laubscher, Militaria 20(2) 1990 : 5-27.

Ebinger, C.K. External Intervention in Internal War; The Politics and Diplomacy of the Angolan Civil War, Orbis 20(3) Fall 1976.

Grundy, K.W. The Militarization of South African Politics. Bloomington, 1984.

Heitman, H.R. Operations Modulêr and Hooper, 1987-1988, South african defence force review 1989 : 275-293. [also Afrikaans trans 'Operasies Modulêr en Hooper, 1987-1988'.]

Heitman, H.R. War in Angola; The Final South African Phase. Gibraltar, 1990. 
Herbstein, Denis and John Evenson The Devils are Among Us; The War for Namibia. London and New Jersey, 1989.

Hooper, J. Koevoet! Johannesburg, 1988.

James, W. Martin A Political History of the Civil War in Angola, 1974-1990. New Brunswick and London, 1992.

Jooste, L. Die SA Weermag in Suidwes-Afrika, 1969-1973. Military Archives Depot, Pretoria, n.d.

Kahn, Owen (ed.) Disengagement from South West Africa; The Process of and Prospects for Peace in Angola. New Brunswick, 1990.

Katjavivi, Peter A History of Resistance in Namibia. London, 1988.

Klinghoffer, A.J. The Angolan War; A Study in Soviet Policy in the Third World. Boulder, Colorado, 1980.

Legum, Colin and Tony Hodges After Angola; The war over Southern Africa. New York, 1976.

Luyt, N. The Accord of Nkomati, Journal for contemporary history Dec 1984.

Luyt, N. Veiligheidsraadsresolusie 435, Journal for contemporary history Dec 1984.

Luyt, N. Hakkejagoperasies ("Hot Pursuit"); volkeregtelike perspektief, Journal for contemporary history Dec 1985.

Luyt, N. Suid-Afrikaanse Veiligheidsmag se aanvalle in Zambië, Zimbabwe en Botswana, Journal for contemporary history Aug 1986.

Meyer, H.P. UNITA as bevrydingsbeweging in Angola, 1963-1982 (unpub ms 1982).

Meyer, H.P. Russiese betrokkenheid in Angola, 1974-1982 (unpub ms 1982).

Nothling, C.J. Kort kroniek van militere operasies en optredes in Suidwes-Afrika en Angola, 19141988, Militaria 19(2) $1989:$ 5-18.

Nothling, C.J. Militere Kroniek van Suidwes-Afrika, 1915-1988, Suid-afrikaanse weermag oorsig 1989 : 233-273. [also English trans- 'Military Chronicle of South West Africa, 1915-1988'.]

Pereira, A.W. The neglected tragedy; the return to war in Angola, 1992-3, Journal of modern African studies 32(1) 1994 : 1-28.
Smith, Susanna Namibia; $A$ Violation of Trust. Oxford, 1987.

Snyman, P.H.R. Beeld van die SWA Gebiedsmag. Pretoria, 1989.

Soggot, David Namibia; The Violent Heritage. London, 1986.

Spies, F.J.du T. Operasie Savannah; Angola 19751976. Pretoria, 1989.

Stander, S. Like the Wind; The Story of the South African Army. Cape Town, 1985.

Steenkamp, W. Borderstrike! South Africa into Angola. Durban, 1983.

Steenkamp, W. South Africa's Border War, 19661989. Gibraltar, 1989.

Stiff, P. Nine Days of War. Alberton, 1989.

SWAPO To be Born a Nation; The Liberation Struggle for Namibia. London, 1981.

Tötemeyer, Gerhard Namibia, Old and New: traditional and modern leaders in Ovamboland. London, 1978.

Tötemeyer, Gerhard, Vezera Kandetu and Wolfgang Werner (eds) Namibia in Perspective. Windhoek, 1987.

Vance, Cyrus Hard Choices; Critical Years in American Foreign Policy. New York, 1983.

Van der Merwe, J.C.K. Revolusionêre Oorlogvoering volgens die Suidwes-Afrika/ Namibië-model, Militaria 25(1) 1994 : 35-62.

Van der Waals, W.S. Angola, 1961-1974: ' $n$ studie in rewolusionêre oorlog (unpub D Phil thesis, UOVS 1990).

Van der Waals, W.S. Portugal's War in Angola, 1961-1974. Rivonia, 1993.

Vigne, Randolph SWAPO of Namibia; a movement in exile, Third world quarterly 9(1) 1987 : 85-107.

Visser, J.A. Burgersake in Suidwes-Afrika; Die Suid-Afrikaanse Weermag se bydrae tot die ontwikkeling van Suidwes-Afrika (unpub ms n.d.).

Wilkinson, Anthony R. Insurgency in Rhodesia 1957-1973; An Account and Assessment, Adelphi papers 100 Autumn 1973. 


\section{CORPS, REGIMENTAL AND UNIT HISTORIES}

Anon. A short history of the Base Post office, Durban, 1940-1946, Militaria 2(6) $1970:$ 52-68.

Adler, F.B. The history of the Transvaal Horse Artillery. Johannesburg, 1927.

Albertse, P.J. and P.J. Brink Short history of No 3 Squadron, SAAF, Militaria 2(1) $1970: 111-113$.

Anderson, K. Nine Flames. Cape Town and Johannesburg, 1964.

Bailey, H. A history of the Seventy-First Seige Battery, South African Heavy Artillery; From July 1915, The Date of its Formation in Cape Town, to the 11th November 1918, when 'Ceasefire' Sounded at Lesdain, on the Escault Canal, near Tournai, Belgium. No publication details available.

Barnard, Leo Pantser in Aksie: 1 SDB 1933-1993. Bloemfontein, 1993.

Bergh, A.C. Short history of No 25 Squadron, SAAF, Militaria 2(1) 1970 : 118-121.

Birkby, C. The Saga of the Transvaal Scottish Regiment, 1932-1950. Cape Town, 1950.

Bouch, R.J. (ed) Infantry in South Africa, 16521976. Pretoria, 1977.

Brink, P.J. Short history of No 15 Squadron, SAAF, Militaria 2(1) 1970 : 114-117.

Brink, P.J. Short history of No 40 Squadron, SAAF, Militaria 2(1) 1970 : 122-125.

Brown, J.Ambrose Prince Alfred's Guard, 18561966. Cape Town, 1967.

Castle, I. Frontier armed and mounted police, Soldiers of the queen $621990: 15-19$.

Changuion, L. Letaba-kommando's/commandos, 1889-1989. Tzaneen, 1989.

Clinometer, 1st Medium Regiment (S.A.N.A.), SAA, Militaria 16(4) $1986:$ 1-16.

Coleman, F.L. 'Nunc Animis'; The Kaffrarian Rifles, 1876-1986. East London, 1988.

Combrinck, J.A. Die Geskiedenis van Regiment President Steyn, 1934 tot 1976 (unpub MA dissertation, UNISA 1983).

Crook, L.A. Ubique - the gunners of South Africa, Militaria 13(3) $1983: 62-76$.
Crook, L.A. Young's Field; A history of the AntiAircraft School. Cape Town, 1991.

Curson, H.H. The history of the Kimberley Regiment. Kimberley, 1963.

Curson, H.H. History of the South African Veterinary Corps, 1910-1939. Pretoria, 1944.

De Jager, P.J. Ottosdal Kommando, 1949-1989; Die geskiedenis van sy ontstaan en ontwikkeling uit die ou Kommando's van Potchefstroom, Lichtenburg en Hartsrivier van 1852 tot vandag. Potchefstroom, 1989.

Douglas, W.S. Regimental history of the Cape Town Highlanders. Cairo, 1944.

Du Plessis, A.J. The Umvoti Mounted Rifles, 18641975. Pietermaritzburg, 1975.

Du Plessis, T.A.P. Die Geskiedenis van Regiment Botha, 1934-1946 (unpub MA dissertation, UP 1983).

Du Preez, S. Vliegopleidingskool Langebaanweg, Militaria 5(4) 1975 : 28-51.

Ferreira, S.J. Die Suid-Afrikaanse Motorfietskorps, Militaria 8(3) 1978 : 11-19.

Fourie, D. The South African Corps of Marines, Military history journal 1(1) Dec 1967 : 32-33.

Gibson, G.E. The Story of the Imperial Light Horse in the Southern African War 1899-1902. Johannesburg, 1937.

Glatthaar, L. Short history of No 41 Squadron, SAAF, Militaria 2(1) 1970 : 126-128.

Goetzsche, E. 'Rough but ready'; An official history of the Natal Mounted Rifles and its antecedent and associated units, 1854-1969. Durban, 1973.

Gomm, N. The South African Army College, Military history journal 2(3) Jun 1972 : 77-81.

Griffiths, R. First City; A Saga of Service. Cape Town, 1970.

Grobler, J.E.H. Die Administratiewe Dienskorps, Militaria 7(3) 1977 : 18-29.

Hattersley, A.F. Carbineer; The History of the Royal Natal Carbineers. Aldershot, 1950.

Hurst, G.T. History of the Natal Mounted Rifles. Durban, 1935. 
Hurst, G.T. Short history of the Volunteer Regiments of Natal and East Griqualand; Past and Present. Durban, 1945.

Jacobs, F.J. et al South African Corps of Signals/ Suid-Afrikaanse Seinkorps. Pretoria, 1975.

Jeffrey, D.V. The 8th Field Squadron. Johannesburg, c.1946.

Jooste, L. Die geskiedenis van Genieskool/The history of School of Engineers, 1940-1990. Cape Town, 1990.

Juta, H.C. The History of the Transvaal Scottish, 1902-1932. Johannesburg, 1933.

Keene, J.L. The Northern Rifles, Museum review 2(1) $1988: 1-9$.

Klein, H. Light Horse Cavalcade; The Imperial Light Horse, 1899-1961. Cape Town, 1969.

Klein, H. Springboks in Armour; The South African Armoured Cars in World War II. Cape Town, 1965.

Little, I.C. In the wake of HMS Dragon, Militaria 23(3) $1993: 14-20$.

Lorch, A.E. A story of the Cape Mounted Riflemen, 1st August, 1878 - 31st March, 1913, and 1st Regiment South African Mounted Riflemen, 1st April, 1913 - 1st April, 1926. Pretoria, 1958.

Martin, A.C. The Durban Light Infantry, vol 1, 18541934. Durban, 1969.

Martin, A.C. The Durban Light Infantry, vol 2, 19351960. Durban, 1969.

McKenzie, A.G. The Dukes; a history of the Duke of Edinburgh's Own Rifles, 1855-1956. Cape Town, 1957.

Meyer, A.C. The history of 276 Squadron, SAAF, Militaria 4(3) 1974 : 51-57.

Mitchell, James H. Tartan on the Veld; The Transvaal Scottish, 1950-1993. Johannesburg, 1994.

Monick, S. A Bugle Calls; The story of the Witwatersrand Rifles and its predecessors, 1899-1987. Germiston, 1989.

Monick, S., and O.E.F. Baker Clear the Way ('Faugh-a-ballagh'); The military heritage of the South African Irish, 1880-1990. 2 vols. Johannesburg, 1991.
Murray, L.G. First City/Cape Town Highlanders in the Italian Campaign, 1943-1945. 1946.

Nortier, D. and R. Robinson 7 Squadron in World War 2, 1942, part 1, Militaria 5(2) 1975 : 1-9.

Nortier, D. and R. Robinson 7 Squadron in World War 2, 1943-1945, part 2, Militaria 5(3) 1975 : $52-65$.

Nortier, D. and R. Robinson Post-war history of No 7 Squadron, part 3, Militaria 5(4) 1975 : 4448.

Nothling, C.J. (ed) Ultima Ratio Regum; Artillery History of South Africa. Pretoria, 1987.

Orpen, N. Gunners of the Cape; The story of the Cape Field Artillery. Cape Town, 1965.

Orpen, N. Prince Alfred's Guards, 1856-1966. Cape Town, 1967.

Orpen, N. The Cape Town Highlanders, 18851970. Cape Town, 1970.

Orpen, N. The Cape Town Highlanders, 18851985. Cape Town, 1986.

Orpen, N. The Cape Town Rifles (The Dukes), 1856-1984.

Orpen, N. The History of the Transvaal Horse Artillery, 1904-1974. Johannesburg, 1975.

Orpen, N. and H.J. Martin Salute the Sappers, Part 1; The formation of the South African Engineers Corps and its operations in East Africa and the Middle East to Battle of Alamein. Johannesburg, 1981.

Orpen, N. and H.J. Martin Salute the Sappers, Part 2; The operations of the South African Engineers Corps in the North African and Italian theatres of war from the Battle of El Alamein to the end of World War II, with a brief description of subsequent developments. Johannesburg, 1982.

Otto, W. Die Spesiale Diensbataljon, 1933-1973. Pretoria, 1973

Parsons, F.J. History of the 72nd Seige Battery, South African Heavy Artillery. Hastings, United Kingdom, 1924.

Payne, S.H.C. SAS Inkonkoni, 1885-1985. Cape Town, 1990.

Perridge, F. The History of Prince Alfred's Guard, 1856-1938. Port Elizabeth, 1939. 
Plane, A. Prepare to mount; The story of the 6th Mounted Regiment. Cape Town, 1977.

Ploeger, J. 26-Eskader RFC, Militaria 2(1) 1970 : 68-78.

Simpkins, B.G. Rand Light Infantry. Cape Town, 1965.

Smy, Ken History of No. 60 Squadron, S.A.A.F., Air Pictorial Feb 1979 : 54-58.

Spring, Ivan Flying Boat; The history of 262 Squadron RAF and the origins of 35 Squadron SAAF. Johannesburg, 1995.

Stratford, D.O. Military Veterinary Services in South Africa, Military history journal 1(6) Jun $1970: 29-30$.

Stratford, D.O. and H.M. Collins Military Nursing in South Africa, 1914-1994. Pretoria, 1994.

Tylden, G. The armed forces of South Africa, with appendix on the commandos. Johannesburg, 1954.

Uys, Ian Bushman Soldiers; Their Alpha and Omega. Germiston, 1993.

Van Broembson, S.E. The story of men; $A$ brief history of the Regiment De la Rey and the Witwatersrand Rifles and their association. Potchefstroom, 1948.

Van der Waag, I.J. In service of the fatherland (Pro Patria - a concise history of the Natal Carbineers), Salut 2(9) Sep 1995, pp.42-45.

Van Jaarsveldt, A.E. et al Militêre Geneeskunde in Suid-Afrika, 1913-1983. Pretoria, 1983.

Visser, G.E. Die Geskiedenis van die Middellandse Regiment, 1934-1943 (unpub MA dissertation, UNISA 1983).

Visser, G.E. Die Middellandse Regiment, Militaria 8(4) $1978: 13-18$.

Whiteford, I.A.St.C The history of the Natal Field Artillery, 1862-1942. Pietermaritzburg, 1972.

Williams, Basil Record of the Cape Mounted Riflemen. London, 1909.

Wood, L.L.F. The Imperial Cape Mounted Riflemen, The coelacanth: the journal of the Border Historical Society 28(2) 1990 : 34-37.

Young, P.J. Boot and saddle; a narrative record of the Cape Regiment, the British Cape Mounted Riflemen, the Frontier Armed Mounted Police and the Colonial Cape Mounted Riflemen. Cape Town, 1955.

\section{STAFF DIVISION, ADMINISTRATIVE AND OFFICE HISTORIES}

Adams, D.L. A history of the Personnel function in the South African Defence Force (ms, Military Archives Depot, June 1988).

Adams, D.L. An organisational history of the Finance function within the Union Defence Forces and South African Defence Force since 1912 (ms, Military Archives Depot, March 1989).

anon. Kantoorgeskiedenis van die Kwartiermeester-generaal en die Hoof van Staf Logistiek (ms, Military Archives Depot, n.d.).

Bantjes, H. Organisatoriese Geskiedenis van die Kantoor van die Hoof van Staf Operasies (ms, Military Archives Depot, n.d.).

Bergh, A.C. Die geskiedenis van Afdeling Logistiek, Militaria 12(2) 1982 : 62-66.

Bouch, R.J. The development of the Comptroller's Section, SADF, 1966-1976, Militaria 6(3) $1976: 1-5$

Bredenkamp, J.D. Die ontstaan en ontwikkeling van die Vloot, 1912-1982, Militaria 12(2) 1982 : 31-37.

Bredenkamp, J.D. Die ontstaan en ontwikkeling van die Kwartiermeester-generaal, Militaria 12(2) $1982: 70-74$.

Brits, L. The Chaplain General, Militaria 12(2) $1982: 75-79$.

Dugmore, P.B.G. Organizational development in the South African Defence Force, Militaria 9(3) $1979: 64-69$.

Du Toit, J.J. Die geskiedenis van die Personeelfunksie in die SA Weermag sedert Wêreldoorlog 1 tot 31 Januarie 1981, Militaria 18(4) 1988 : $14-23$.

Jonker, E. Die Militêr-Historiese en Argivale Dienste van die Departement van Verdediging, Militaria 1(1) $1969: 3-26$.

Jooste, L. Die SAW Argief, Suid-Afrikaanse weermag oorsig 1988 : 199-213. [also English trans - 'The SADF Archives'.] 
Jooste, L. and I.J. van der Waag A history of Military Intelligence in South Africa. Military Archives Depot, Pretoria, 1990.

Le Grange, S.C. Die geskiedenis van Hoof van Staf Inligting, Militaria 12(2) $1982: 56-58$.

Le Grange, S.C. Die geskiedenis van Hoof van Staf Operasies, Militaria 12(2) 1982 : 59-61.

Lillie, A.C. The origin and development of the South African Army, Militaria 12(2) 1982 : 7-17.

Lillie, A.C. Chief of Staff Finance, Militaria 12(2) 1982 : 67-69.

Nothling, C.J. Die Inspekteur-generaal in die SuidAfrikaanse Weermag, 1912-1983, Militaria 13(2) $1983:$ 57-65.

Otto, W. Die Direktoraat Openbare Betrekkinge gedurende Wêreld Oorlog 2, Militaria 5(2) 1975: 18-25.

Ploeger, J. Uit die voorgeskiedenis van die SuidAfrikaanse Vloot; die ontstaan van die SuidAfrikaanse Seediens, Militaria 3(1) 1971: 1-80.

Pretorius, C.M.L. Die SAGD - sy ontstaan en ontwikkeling, Militaria 12(2) 1982 : 38-45.

Stratford, D.O. Die Amp van Sekretaris van Verdediging, Military history journal 1(3) Dec $1968: 9-10$.

Von Moltke, R. Die ontstaan en ontwikkeling van die stafafdeling Hoof van Staf Personeel, Militaria 12(2) $1982:$ 46-51.

\section{REGIONAL}

Bisset, W.M. The Union Defence Force's Buildings of Cape Town during the Second World War, Militaria 18(1) $1988: 53-57$.

Brann, R.W. Wynberg military base and the Army Officers' Club, Militaria 19(1) 1989 : 1-11.

Burman, J. and S. Levin The Saldanha Bay Story. Cape Town and Pretoria, 1974.

Du Preez, S. Voortrekkerhoogte 90 jaar oud, Militaria 19(1) 1989 : 12-30.

Fuchs, D.R. Durban during the Second World War, c.1939-1945: a study of war and social change (unpub MA dissertation, UN 1990).

Groenewald, A.J. Die Geskiedenis van Tempe as militêre basis tot 1960 (unpub MA dissertation, UOVS 1984).
Hummel, H.C. Some reflections on the history of Port Alfred in the aftermath of World War II, Contree; journal for South African urban and regional history 351994 : 1-10.

Newman, C. East London in the 1930s and 1940s (extract from a private journal), Coelacanth; the journal of the Border historical society 32(2) $1994: 21-36$.

Ploeger, J. Besonderhede aangaande ' $n$ aantal geboue op die terrein van die huidige Verdedigingshoofkwartier, Potgieterstraat, Pretoria, Militaria 2(2) $1970: 1-25$.

Ploeger, J. Die bou van die Staatsartilleriekaserne, Potgieterstraat, Pretoria: die uitbreiding in 1924 om die Hoofkwartier van die Unieverdedigings= mag te huisves, Militaria 13(4) 1983 : 28-32.

Ploeger, J. Die naamgewing van die dorp Pierre van Ryneveld (Van Ryneveldpark) en sy uitbreidings, Militaria 20(1) $1990: 13-23$.

Van der Merwe, P.R. Die militêre geskiedenis van die Oranje-Vrystaat, 1910-1920 (unpub MA dissertation, UOVS 1987).

Van der Waag, I.J. Naval history of Saldanha, Paratus 45(1) Jan 1994 : 45-46.

Visser, Deon Bewakers van die baai; Die nalatenskap van die Tweede Wêreldoorlog is vandag nog sigbaar in Saldanha, Salut 2(5) May 1995, pp.56-57.

\section{SOCIAL}

Cronje, J.I. Militêre Maatskaplike Werk in SuidAfrika - riglyne vir die voorbereiding van maatskaplike werkers met betrekking tot hulle taak teenoor militere personeel (unpub MA dissertation, US 1979).

Ferreira, R. Die invloed van Grensdiens op die rolvervulling in die Gesin (unpub MA dissertation, UNISA 1984).

Henning, P.H. Die Betrokkenheid van Nasionale Dienspligtiges by Kerklike Aktiwiteite (MS. 1983)

Potgieter, J.F. Die Militêre Kapelaan; Die Ontstaan en Ontwikkeling van die Amp, Taak en Organisasie van Militêre Kapelane in die geskiedenis van die Christelike Kerk, met besondere verwysing na Suid-Afrika (unpub DD thesis, UP 1971).

Pretorius, W.J. Die taak van die Maatskaplike Werker tydens mobilisasie en demobilisasie met 
besondere verwysing na die Republiek van SuidAfrika (unpub Ph D thesis, UP 1972).

Prinsloo, M. Die invloed van Burgermagverpligtinge op die gesin (unpub M Soc Sc dissertation, UOVS 1987).

\section{MILITARY CULTURE}

Anon. Military customs and traditions, Militaria 11 (3) $1981: 38-40$.

Anon. Military customs and traditions, Militaria 11(4) $1981: 34-39$.

Anon. Military customs and traditions, Militaria 12(1) $1982: 32-34$

Anon. Military customs and traditions, Militaria 12(3) $1982: 51-53$.

Anon. Military customs and traditions, Militaria 12(4) $1982: 44-46$.

Baker, O.E.F. The South African Irish Regiment; An example of the Military Traditions of the Irish in South Africa, Military history journal 6(1) Jun $1983: 21-30$

Chambers, R. Art and propaganda in an age of war; The role of posters, Militaria 13(4) 1983 : 54-59.

Cousins, F.A.M. Military music in South Africa; A critical study of its use in time of peace and its potential in time of war, together with constructive ideas for increasing efficiency, Militaria 11(3) 1981: 1-8.

Cowling, N.M. A history of Military Nomenclature in South Africa, Militaria 23(3) 1993 : 1-13.

Curson, H.H. Colours and Honours in South Africa. Pretoria, 1948.

Curson, H.H. Regimental devices in South Africa, 1783-1954. Pretoria, 1954.

Fourie, D.F.S. Waar ontstaan ons militere tradisies dan?, Militaria 11(3) 1981 : 35-37.

Grobbelaar, P. Die Oorsprong van Militêre Kultuur aan die Kaap, Suid-Afrikaanse weermag oorsig 1990 : 289-317 [also English trans - 'The Origin of Military Culture at the Cape'.]

Henry, R. Regimental colours, Military history journal 9(6) 1994 : 228.

Imrie, J.M.M. The Military Band in South Africa. Pretoria, 1976.
Jooste, L. Die Kuns van Oorlog; ' $n$ Inleiding tot militêre kuns in Suid-Afrika. Pretoria, n.d.

Jooste, L. The Art of War; An introduction to military art in South Africa. Pretoria, n.d.

Monick, S. Shamrock and Springbok; The Irish impact on South African military history, 16891914. Johannesburg, 1989.

Picard, J.H. Military traditions with special reference to South Africa, Militaria 20(1) 1990 : 1-12.

Slater, C.G. The Problem of Purchase Abolition in the British Army, 1856-1862, Military history journal 4(6) Dec 1979 : 225-235.

\section{MESSES, CANTEENS AND ENTERTAINMENT}

Bantjes, H. Die Vermaaklikheidsgroep van die Unie-Verdedigingsmag gedurende die Tweede Wêreldoorlog: ' $n$ historiese ontleding (unpub MA dissertation, UP 1990).

Bredenkamp, J.D. The history of the Naval Mess (Union Hotel), Pretoria, Militaria 14(1) 1984 : 14-18.

Kotze, H.A. 'n Nuwe perspektief op die saamleef van soldate, Militaria 13(3) $1983: 54-57$.

Miller, H. Service to the Services; The story of NAAFI. London, 1971.

Ponsford, T.R. War Record of Union Defence Force Institutes (YMCA-Toc H), 1939-1946. Cape Town, n.d.

Swift, M.H. The Union Defence Force Entertainment Group in South Africa, World War 2, Militaria 4(2) $1974: 26-38$.

Swift, M.H. The Union Defence Force Entertainment Group in the Middle East, Militaria 4(3) $1974: 36-50$.

Van der Waag, I.J. A history of the South African Defence Force Institute (SADFI), 1914-1990. Pretoria, 1991.

Van der Waag, I.J. A history of the South African Defence Force Institute, 1916-1991, Militaria 21(3) $1991: 27-43$.

Van der Waag, I.J. Serving the Services; a concise history of the SA Defence Force Institute, Paratus 40(6) Jun 1989 : 32-35. 


\section{UNIFORMS AND MEDALS}

Adler, F.B. Military medals of South African interest. Johannesburg, 1957.

Alexander, E.G.M. et al South African Orders, Decorations and Medals. Pretoria and Cape Town, 1986.

Bisset, W.M. Die uniformknope van die SuidAfrikaanse Vloot en sy voorgangers, Militaria 10(4) $1980: 39-41$.

Bisset, W.M. A short history of the development of South Africa's naval uniform, Militaria 11(2) 1981 : 38-46.

Bisset, W.M. Nominal Roll of S.A. Defence Force Recipients of the King George VI Coronation Medal 1937, Military history journal 2(2) Dec 1971 : 65-68.

Bisset, W.M. King George VI Coronation Medal 1937, Military history journal 3(3) Jun 1975 : 104-108.

Digby, P.K.A. The origin of the badges and uniform of the Transvaal Scottish, Africana notes and news 23(2) Jun $1978: 69-75$.

Duxbury, G.R. Changes in Ranks and Designations in the South African Defence Force, Military history journal 1(2) Jun $1968: 36$.

Duxbury, G.R. Louw Wepener Medal, Military history journal 1(1) Dec $1967:$ 36-37.

Duxbury, G.R. Pro Merito Medal, Military history journal 1(2) Jun $1968: 27$.

Fforde, J.P.I. and S. Monick A guide to South African orders, decorations and medals and their ribbons, 1896-1985. Johannesburg, 1986.

Monick, S. South African military awards, 19121987. Johannesburg, 1988.

Monick, S. Awards of the South African uniformed public services, 1922-1987. Johannesburg, 1988.

Owen, C.R. The Military Badges of South Africa and Rhodesia from 1850-1975. Johannesburg, 1976.

Uys, I. Cross of Honour. Germiston, 1992.

Van Wyk, A. Honoris Crux, Ons Dapperes - Our Brave. Cape Town, 1982.

Van Wyk, A. Honoris Crux, Ons Dapperes II. Cape Town, 1985.

\section{CONSERVATION}

Anon. The SADF and conservation, Militaria 13(1) $1983:$ 35-37.

Anon. The SADF and conservation, Militaria 13(2) $1983: 66-69$.

Anon. The SADF and conservation, Militaria 13(3) $1983: 61$.

Klein, W. Die rol van die SAW in Natuur en Omgewingsbewaring, Militaria 18(1) 1988 : 2838.

Loubser, J. and D.P. Stoffberg SADF early iron age excavations in the Tugela valley, Militaria 14(4) $1984: 27-39$.

\section{BIOGRAPHY AND AUTOBIOGRAPHY}

Anon. A Machine Gunner's Odyssey Through German East Africa; The Diary of E.S. Thompson January 1916 - February 1917, Military history journal 7(3) Jun $1987:$ : 85-89.

Anon. A Machine Gunner's Odyssey Through German East Africa; The Diary of E.S. Thompson, Part 1: 17 January - 24 May 1916, Military history journal 7(4) Dec 1987 : 127-140.

Anon. A Machine Gunner's Odyssey Through German East Africa; The Diary of E.S. Thompson, Part 2: 25 May - 17 September 1916, Military history journal 7(5) Jun $1988: 163-179$.

Anon. A Machine Gunner's Odyssey Through German East Africa; The Diary of E.S. Thompson, Part 3: 18 September - 26 February 1917, Military history journal 7(6) Dec 1988 : 220-233.

Baker, E.C.R. Ace of Aces; M. St.J. Pattle: Top Scoring Allied Fighter Pilot of World War II. Johannesburg, 1992 (reprint).

Barnett, C. The Desert Generals. London, 1960.

Bernstein, B.L. The Tide Turned at Alamein; Impressions of the Desert War with the South African Division and the Eighth Army, June, 1941 - January, 1943. Central News Agency, South Africa, no date.

Birkby, C. Uncle George; A Biography on Gen G.E. Brink. Johannesburg, 1987.

Blamey, A.E. A Company Commander Remembers; From El Yibo to El Alamein. Pietermaritzburg, 1963. 
Blamey, A.H.G. My Verulam Troop; Being a Short Account of the Verulam Troop of the Natal Mounted Rifles and of their Movements and Engagements when they were Seconded to the Durban Light Infantry in the Zulu Rebellion of 1906. Port Shepstone, n.d.

Boydell, T. My luck was in; With spotlight on General Smuts. Cape Town, n.d.

Brink, J. Genl-maj sir Henry Timson Lukin, Militaria 5(3) $1975:$ 40-51.

Broll, Maurice Mud, Blood and Laughter. War Fund Books, Cape Town, 1943.

Buxton, Lord General Botha. London, 1924.

Castle, I. Thomas Munro Carbutt; A Yorkshireman in Africa, Soldiers of the queen 691992 : 9-13.

Crafford, F.S. Jan Smuts; A Biography. Cape Town, 1946.

Crimp, R.L. The Diary of a Desert Rat (edited by Alex Bowlby). London, 1971.

Cross, N. An Escape Story, Military history journal 6(2) Dec $1983:$ 44-50.

Cunningham, R.I. The Turning Point, 3rd July 1942; An eye-witness account, Military history journal 6(5) Jun $1985:$ 169-174.

Dimbleby, D.G. Hostilities Only. Cape Town, 1944.

Du Toit, C.L.de W. Herinneringe van Genl. Christiaan Ludolph de Wet du Toit, deel 1, Militaria 10(2) $1980: 7-24$.

Du Toit, C.L.de W. Herinneringe van Genl. Christiaan Ludolph de Wet du Toit, deel 2, Militaria 10(3) $1980: 1-27$.

Du Toit, C.L.de W. Herinneringe van Genl. Christiaan Ludolph de Wet du Toit, deel 3, Militaria 10(4) 1980: 1-23.

Dutton, J.R. Personal aspects of the Korean war, 1952-1953 [ms, Military Archives Depot, Pretoria, 1992].

Engelenburg, F.V. General Louis Botha. Pretoria, 1929.

Geldenhuys, Jannie A General's Story from an era of war and peace. Johannesburg, 1995.

Girard, C.S.M. Canadian Nurses in the South Af- rican Military Nursing Service; Some Reminiscences Forty Years Later, Military history journal 6(1) Jun $1983:$ 6-10.

Hall, D.D. The 1917 Diary of 2/Lt R.E. Stevenson, Military history journal 7(1) Jun 1986 : 1-12, 23.

Hancock, W.K. Smuts; The Fields of Force, 19191950. Cambridge, 1968.

Hartshorn, E.P. Avenge Tobruk. Cape Town and Johannesburg, 1960.

Hugo, B. Betty Freund: A nurse in France, part 1, Militaria 15(1) $1985: 1$-14.

Hugo, B. Betty Freund: A nurse in France, part 2, Militaria 15(2) $1985:$ 1-16.

Hugo, B. Betty Freund: A nurse in France, part 3, Militaria 15(4) $1985: 11-22$.

Hugo, B. Betty Freund: A nurse in France, part 4, Militaria 16(1) $1986:$ 40-50.

Hugo, B. Betty Freund: A nurse in France, part 5, Militaria 16(3) $1986:$ 1-23.

Judd, B.C. Major General Sir Henry Timson Lukin, KCB, CMG, DSO, Military history journal 7(3) Jun $1987:$ 124-125.

Kasrils, R. Armed and Dangerous; My undercover struggle against Apartheid. Gaborone, 1993.

Kroukamp, W.J. Lt A.W. Beauchamp-Proctor die klein mannetjie met die leeumoed, Militaria 14(1) 1984 : 29-31.

Kroukamp, W.J. Sersant Quentin George Murray Smythe - ' $n$ man van durf en daad, Militaria 14(2) $1984: 23-24$.

Kroukamp, W.J. Lt-kdr D.A. Hall, die groothartige skipper, Militaria 14(4) 1984 : 40-43.

Le Riche, P.J. Memoirs Brigadier-General Ben Bouwer (ms, n.p., n.d.).

Malherbe, E.G. Never a Dull Moment. Lansdown, 1981.

Mahncke, A. and J. Into the Fire; A German Officer's Impressions of the Western Front, 1917, Military history journal 7(3) Jun 1987 : 113-121.

Mahncke, J. Assult on Sicily, 1943; An account based on the Kriegstagebuch des Oberkommandos der Wehrmacht, and the autobiography of General der Flieger Alfred Mahncke with 
special emphasis on the activities of the Luftwaffe, Military history journal7(2) Dec 1986: 70-78.

Mandela, N. No easy walk to freedom. New York, 1965.

Matthews, Z.K. Freedom for my people; The autobiography of Z.K. Matthews, Southern Africa 1901-1968. London, 1981.

Mejier, J.W. Die Vroeë militêre loopbaan van generaal Ben Viljoen, 1896-1898, Historia 39(2) 1994 : 50-66.

Pollock, A.M. Pienaar of Alamein. Cape Town, 1943.

Raugh, H.E. Training ground for a future Field Marshal; Wavell in the Boer War and Edwardian India, 1901-1908, Journal of the society for army historical research 72(289) $1994: 8-18$.

Rosenthal, E. General de Wet. Cape Town, 1968.

Scott-Shaw, C. Looking Back With Laughter; The saga of a South African student, soldier and sky pilot in Korea. Pietermaritzburg, 1973.
Soule, A., G. Dixon and R.Richards The Wynand du Toit Story. Johannesburg, 1987.

Trew, H.F. Botha Treks. London and Glasgow, 1937.

Uys, Ian South African Military Who's Who, 14521992. Germiston, 1992.

Van Coller, H.P. General P.A. Cronje. Pretoria, 1945.

Van der Waag, I.J. Colonel (Dr) Jan Ploeger, 19131994, Militaria 24(2) 1994 : 3-4.

Van der Waag, I.J. Lieutenant-Colonel Hon. H.A. Wyndham (the 4th Lord Leconfield): Odyssey of an English gentleman in Africa, 1901-1930 [ms, Military Archives Depot, Pretoria, 1995].

Van der Waag, I.J. Major J.G.W. Leipoldt, D.S.O.: A portrait of a South African surveyor and intelligence officer, 1913-1923, Militaria 24(3) 1994: 12-34.

Weinronk, Jack 'Cobber' The Vaulted Sky; A Bomber Pilot's Western Desert War. Braunton, 1993. 